\title{
Serviceability limit state of two-way reinforced concrete slab strengthened with different techniques
}

\author{
Eyad Sayhood ${ }^{1, *}$, Ammar Ali ${ }^{1}$, and Zahraa Sharhan ${ }^{1}$ \\ ${ }^{1}$ Building and Construction Engineering Department, University of Technology, Baghdad, Iraq
}

\begin{abstract}
The experimental results for service load of sixteen simply supported two way reinforced concrete slabs under the action of concentrated patch load were determined based on the amount of permissible deflections and the crack widths.All the slabs had the same overall dimensions and flexural steel reinforcement. Five types of strengthening were adopted. The first and second methods include applying either near surface mounted (NSM) or near reinforcement mounted (NRM) ferrocement layers. While the third method includes applying a concrete layer reinforced with welded wire fabric mesh of various diameters. The fourth and fifth methods include fixing CFRP rods and laminates, respectively, on the bottom surface of slabs. Strengthening techniques were applied on the bottom surface of fifteen slab specimens. In addition, a control slab specimen without any strengthening was used for the purpose of comparison. The calculated results for ultimate loads based on serviceability requirements (deflection and crack width according to both ACI and BS formulae) were lower than the experimental results.
\end{abstract}

\section{Introduction}

Serviceability refers to the conditions under which a structure is still considered useful. It refers to conditions other than the structure strength that render the structures unusable. Serviceability limit state design of structures includes factors such as durability, overall stability, fire resistance, deflection, cracking and excessive vibration. past and have been quite popular. Five of these methods are included in this paper: wire mesh reinforced cement mortar (both NSM and NRM ferrrocement), external welded wire fabric (WWF) reinforced concrete layer, CFRP bars and CFRP laminates.

The advantages of strengthening techniques are well explained in a previous research [1].

\section{Experimental program}

Sixteen simply supported slab specimens were cast. All slabs have the same dimensions of $700 \mathrm{~mm}$ width, 700 $\mathrm{mm}$ length and $130 \mathrm{~mm}$ thickness. A control slab (without strengthening) was designed to fail in flexure as shown in Fig. 1. The steel bars used in reinforcing slab specimens were of size $6 \mathrm{~mm}$ with $150 \mathrm{~mm}$ spacing. The steel bars were added at the bottom face of the slabs in both directions. Fifteen of the specimens were strengthened by different types of strengthening techniques using mesh wires, WWFs, CFRP bars and laminates as shown in Fig. 2. The specimens were classified into five groups GA, GB, GC, GD and GE, and slab G0 was the control specimen. The parametric study was designed to classify slabs into five series, as shown in Table1. Many trial mixes were made to gain a suitable strength. The mix was designed to achieve cylinder compressive strength ( $\mathrm{f}^{\prime} \mathrm{c}$ ) of about $30 \mathrm{MPa}$ at 28 days. The details of the normal concrete mix which was used in this study are shown in Table 2. The mortar that was used in groups GA and GB was of cement-sand mix in the ratio of $1: 2$.

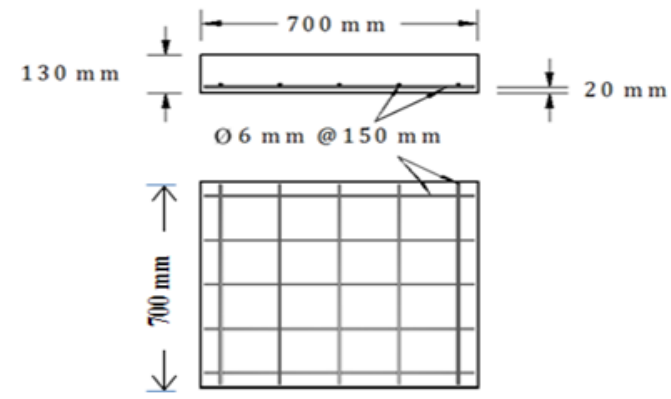

Fig. 1. Details and arrangement of reinforcement of a typical slab specimen

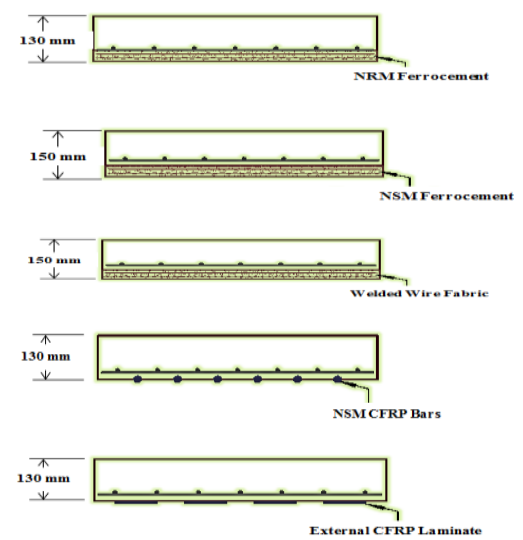

Fig. 2. Strengthening techniques

Corresponding author: dr_eyad_alhachamee@yahoo.com 


\subsection{Concrete mix and mechanical properties}

Each mix batch for all groups were controlled by casting nine standard cylinders of 150x $300 \mathrm{~mm}$, three $150 \mathrm{~mm}$ cubes and three prisms of $100 \times 100 \times 400 \mathrm{~mm}$. These specimens were used to determine the average cylinder compressive strength of concrete of $30 \mathrm{MPa}$, splitting tensile strength ranges between 2.6 to $3.2 \mathrm{MPa}$, flexural strength ranges between 3.8 to $4.6 \mathrm{MPa}$ and the modulus of elasticity ranges between 26.5 to $28.2 \mathrm{GPa}$. Details of the tests and results are given in Ref. 1.

All concrete slab specimens were tested using a testing machine of $700 \mathrm{kN}$ capacity. During the test, central deflection was recorded using a dial gauge with accuracy of $0.01 \mathrm{~mm}$. The first crack was observed, also the corresponding cracking load was recorded, and the crack patterns were marked. Steel plate of $200 \times 200 \times 25 \mathrm{~mm}$ was placed at the center of the slab to represent patch load and to prevent local crushing of concrete. The nominal effective areas of strengthening $\left(A_{t}\right)$ shown in Table 1 were calculated as:

$$
A_{t}=A_{b \times} \frac{1000}{S}
$$

where, $\mathbf{A}_{\mathbf{b}}$ is the area of a single steel wire in mesh reinforcement in groups $\mathrm{A}$ to $\mathrm{C}$ or CFRP bars or strip in groups $\mathrm{D}$ and $\mathrm{E}$ in $\mathrm{mm}^{2}$,

And, $\mathbf{S}$ is the spacing distance between wires, bars or strips, center to center, in $\mathrm{mm}$.
Table 2. Normal concrete mix proportions

\begin{tabular}{|c|c|c|c|c|}
\hline $\begin{array}{c}\text { Cement } \\
\left(\mathbf{k g} / \mathbf{m}^{\mathbf{3}}\right)\end{array}$ & $\begin{array}{c}\text { Water } \\
\left(\mathbf{k g} / \mathbf{m}^{\mathbf{3}}\right)\end{array}$ & $\begin{array}{c}\text { Coarse } \\
\text { aggregate } \\
\left(\mathbf{k g} / \mathbf{m}^{\mathbf{3}}\right)\end{array}$ & $\begin{array}{c}\text { Fine } \\
\mathbf{a g g r e g a t e} \\
\left(\mathbf{k g} / \mathbf{m}^{\mathbf{3}}\right)\end{array}$ & $\mathbf{W} / \mathbf{C}$ \\
\hline 400 & 193 & 990 & 745 & 0.48 \\
\hline
\end{tabular}

\subsection{Test results and discussion}

The cracking loads $\left(\mathbf{P}_{\mathbf{c r}}\right)$, crack widths $\left(\mathbf{W}_{\mathbf{c r}}\right)$, central deflections $(\boldsymbol{\Delta v})$ and ultimate load $\left(\mathbf{P}_{\mathbf{u}}\right)$ are shown in Table 3 . The control slab was designed to fail in flexure. Deflection is considered an important property of any structure. In this study, a central dial gauge with accuracy $0.01 \mathrm{~mm}$ was used to determine the deflection. At low load levels all the tested slabs behaved in an elastic manner where the cracks did not appear at any place and the central deflections are small and proportional to the applied load. The first crack appeared around the sides of the steel plate on the tension face of the slab and other cracks formed at the central region of the slab. By increasing the load, these cracks widened and increased in number and spread to the support of the slab through a diagonal direction. Also new cracks appeared starting from the supports. Eventually the cracks were many and one or more of these cracks had the potential to penetrate into the compression zone at the loading positions. Figs. 3 to 7 explain the loaddeflection relationship of the tested slabs, clearly shows that the usage of the five strengthening techniques reduces the deflection of the slab. It can be noticed that all specimens have undergone three stages of behavior during the entire load process.

Table 1. Details of specimen groups

\begin{tabular}{|c|c|c|c|c|}
\hline Group & Samples & Type of strengthening & $\begin{array}{l}\text { Nominal Area of } \\
\text { Strengthening* } \\
\left(\mathrm{mm}^{2} / \mathrm{m}\right)\end{array}$ & Description \\
\hline G0 & G0 & Without strengthening & ----- & Control specimen \\
\hline \multirow{3}{*}{ GA } & GA1 & \multirow{3}{*}{$\begin{array}{l}\text { Strengthened by NRM } \\
\text { ferrocement }\end{array}$} & 90 & One layer of wire mesh \\
\hline & GA2 & & 180 & Two layers of wire mesh \\
\hline & GA3 & & 270 & Three layers of wire mesh \\
\hline \multirow{3}{*}{ GB } & GB1 & \multirow{3}{*}{$\begin{array}{l}\text { Strengthened by NSM } \\
\text { ferrocement }\end{array}$} & 90 & One layer of wire mesh \\
\hline & GB2 & & 180 & Two layers of wire mesh \\
\hline & GB3 & & 270 & Three layers of wire mesh \\
\hline \multirow{3}{*}{$\mathrm{GC}$} & GC1 & \multirow{3}{*}{ Strengthened by fabric wires } & 90 & $\begin{array}{l}\text { One layer of fabric wires with Ø4 mm } \\
\qquad 150 \mathrm{~mm} \text { spacing }\end{array}$ \\
\hline & $\mathrm{GC} 2$ & & 180 & $\begin{array}{l}\text { One layer of fabric wires with } \varnothing 6 \mathrm{~mm} \\
\qquad 150 \mathrm{~mm} \text { spacing }\end{array}$ \\
\hline & GC3 & & 270 & $\begin{array}{c}\text { Two layers of fabric wires with (Ø4mm } \\
\text { and Ø6 mm)@150mm spacing }\end{array}$ \\
\hline \multirow{3}{*}{ GD } & GD1 & \multirow{3}{*}{ Strengthened by CFRP bars } & 90 & 3 bars at each direction with Ø6mm \\
\hline & GD2 & & 180 & 5 bars at each direction with $\varnothing 6 \mathrm{~mm}$ \\
\hline & GD3 & & 270 & 7 bars at each direction with $\varnothing 6 \mathrm{~mm}$ \\
\hline \multirow{3}{*}{ GE } & GE1 & \multirow{3}{*}{$\begin{array}{c}\text { Strengthened by CFRP } \\
\text { laminates } \\
(1.2 \mathrm{~mm} \text { thickness })\end{array}$} & 90 & $\begin{array}{l}5 \text { strips of carbon laminate with width } \\
\text { of } 15 \mathrm{~mm}\end{array}$ \\
\hline & GE2 & & 180 & $\begin{array}{l}5 \text { strips of carbon laminate with width } \\
\text { of } 30 \mathrm{~mm}\end{array}$ \\
\hline & GE3 & & 270 & $\begin{array}{l}5 \text { strips of carbon laminate with width } \\
\text { of } 45 \mathrm{~mm}\end{array}$ \\
\hline
\end{tabular}

*From Eq. 1 
Table 3. Experimental results of the tested slabs

\begin{tabular}{|c|c|c|c|c|c|c|c|}
\hline $\begin{array}{l}\text { Sample } \\
\text { Name }\end{array}$ & $\begin{array}{c}\mathbf{P}_{\mathrm{cr}} \\
(\mathbf{k N})\end{array}$ & $\begin{array}{c}W_{\mathrm{cr}} \\
(\mathrm{mm}) \\
\text { at } P_{u}\end{array}$ & $\begin{array}{c}\Delta v \\
(\mathrm{~mm}) \\
\text { at } P_{u}\end{array}$ & $\begin{array}{c}\mathbf{P}_{\mathbf{u}} \\
(\mathbf{k N})\end{array}$ & $\begin{array}{c}\mathbf{P}_{\mathrm{cr}} / \\
\mathbf{P}_{\mathrm{u}}\end{array}$ & $\begin{array}{c}\mathbf{P}_{\mathrm{cr}} / \\
\mathbf{P}_{\mathbf{c r} \cdot} \cdot \mathbf{G 0}\end{array}$ & $\begin{array}{c}\mathbf{P}_{\mathrm{u}} / \\
\mathbf{P}_{\mathrm{u} .} \mathbf{G 0}\end{array}$ \\
\hline G0 & 72.1 & 1.3 & 11.2 & 170 & 0.42 & 1 & 1 \\
\hline GA1 & 80.5 & 1 & 7.7 & 176 & 0.46 & 1.11 & 1.04 \\
\hline GA2 & 84 & 0.95 & 7 & 183 & 0.46 & 1.17 & 1.08 \\
\hline GA3 & 86 & 0.9 & 7.3 & 205 & 0.42 & 1.19 & 1.21 \\
\hline GB1 & 79.3 & 1 & 8.7 & 190 & 0.42 & 1.1 & 1.12 \\
\hline GB2 & 85 & 0.98 & 8.5 & 207.7 & 0.41 & 1.18 & 1.22 \\
\hline GB3 & 88.1 & 0.97 & 9.4 & 235 & 0.37 & 1.22 & 1.38 \\
\hline $\mathrm{GC1}$ & 98.9 & 1.2 & 10.8 & 242.2 & 0.41 & 1.37 & 1.42 \\
\hline GC2 & 105 & 1.15 & 10 & 264 & 0.4 & 1.46 & 1.55 \\
\hline GC3 & 106 & 1.1 & 9 & 281.2 & 0.38 & 1.47 & 1.65 \\
\hline GD1 & 121.3 & 1 & 11 & 312 & 0.39 & 1.68 & 1.84 \\
\hline GD2 & 128.1 & 0.95 & 10 & 344.1 & 0.37 & 1.78 & 2.02 \\
\hline GD3 & 131.5 & 0.92 & 10 & 375.1 & 0.35 & 1.82 & 2.21 \\
\hline GE1 & 126.9 & 0.83 & 10.2 & 322 & 0.39 & 1.76 & 1.89 \\
\hline GE2 & 139.4 & 0.8 & 9.5 & 350.2 & 0.4 & 1.93 & 2.06 \\
\hline GE3 & 144.6 & 0.78 & 9.2 & 399.4 & 0.36 & 2.01 & 2.35 \\
\hline
\end{tabular}

At the first stage, the linear behavior of the load deflection response is considered. This stage covers the region up to the first crack load, below this limit the materials behave elastically and the cracks originating in the tensile regions of the specimens cross section are still stable. After this, the cracks spread and their width increases with the increasing load. Both the reinforcement for all groups and mortar for group GA, GB and GC in compression zone are still elastic.

At the second stage, a nonlinear behavior of the load deflection response is noticed. This stage covers the region beyond the proportional limit. A gradual yielding of steel reinforcement occurs, because several layers of mesh are placed at different depths of the cross section, many carbon rods were also placed near surface and several slices of carbon laminate were applied. At this stage, the increase in the load carrying capacity beyond the proportional limit is due to the increase in the tensile stresses accompanied with a continuous shift in the position of the neutral axis towards the compression zone.

Finally, as the applied load reaches near its ultimate value, the rate of increase in deflection is substantially exceeding the rate of increase in the value of applied load. The crack width versus applied load responses of the slab specimens are shown in Figs. 8 to 12.

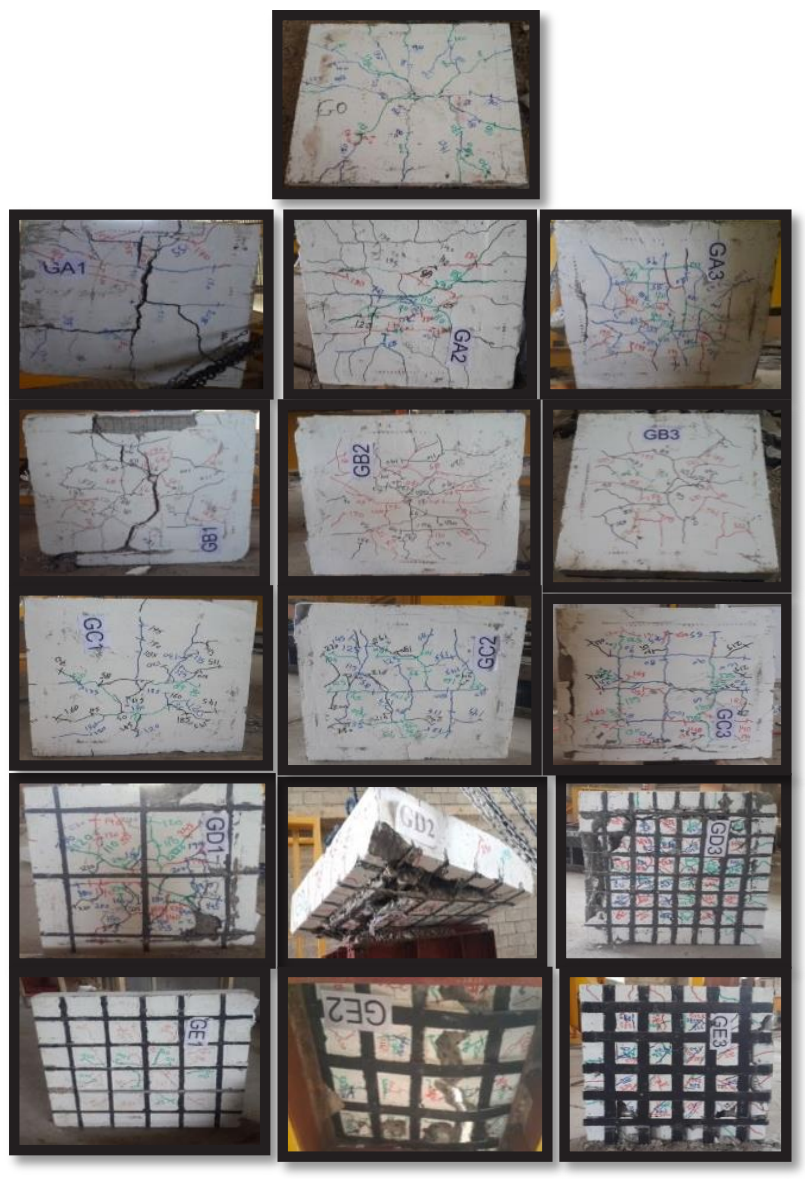

Plate 1. Slab specimens after testing, crack patteren and mode of failure 


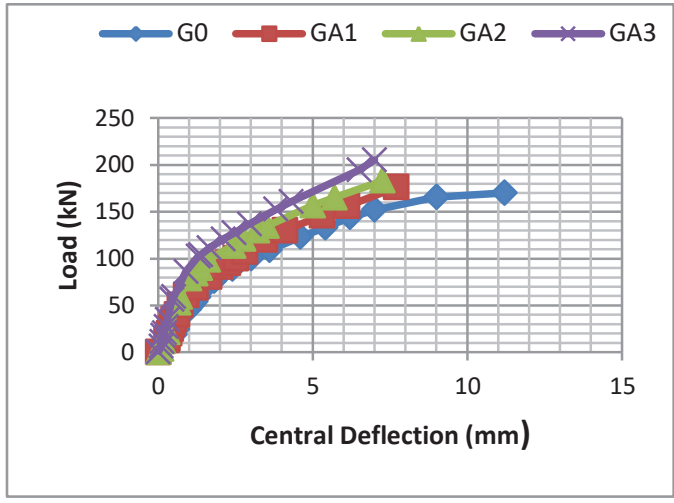

Fig. 3. Load - deflection curve for specimens of group GA

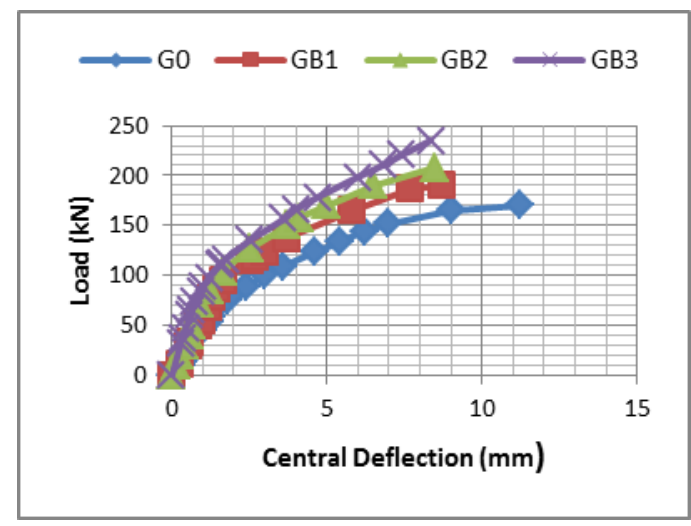

Fig. 4. Load - deflection curve for specimens of group GB

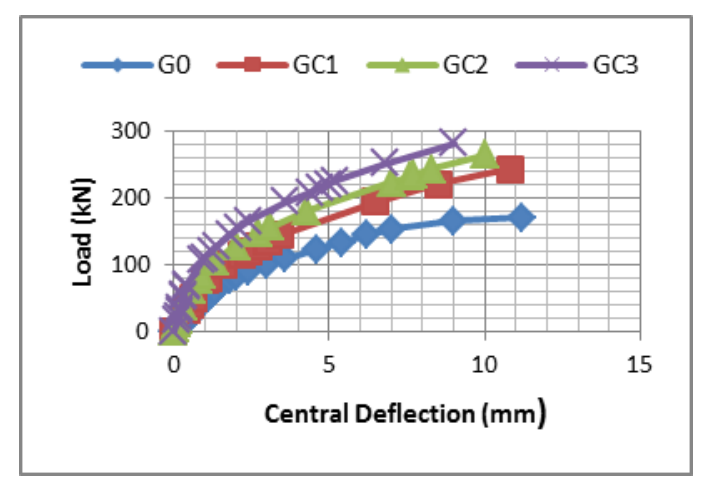

Fig. 5. Load - deflection curve for specimens of group GC

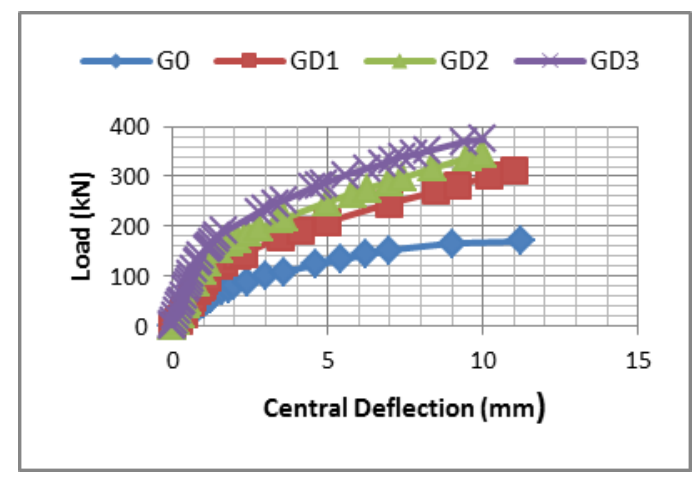

Fig. 6. Load - deflection curve for specimens of group GD

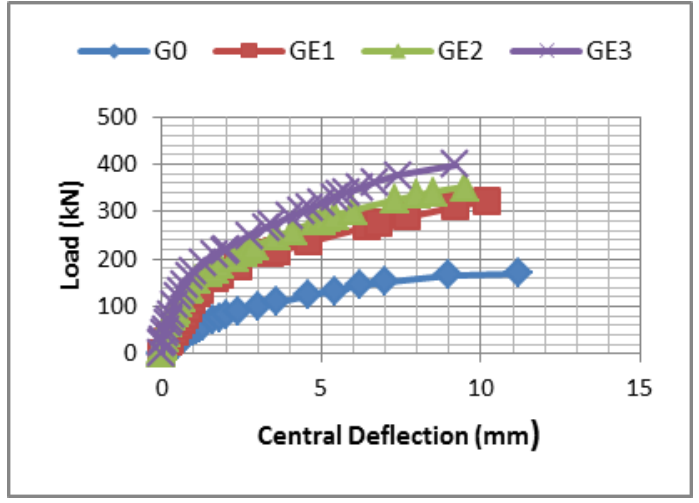

Fig. 7. Load - deflection curve for specimens of group GE

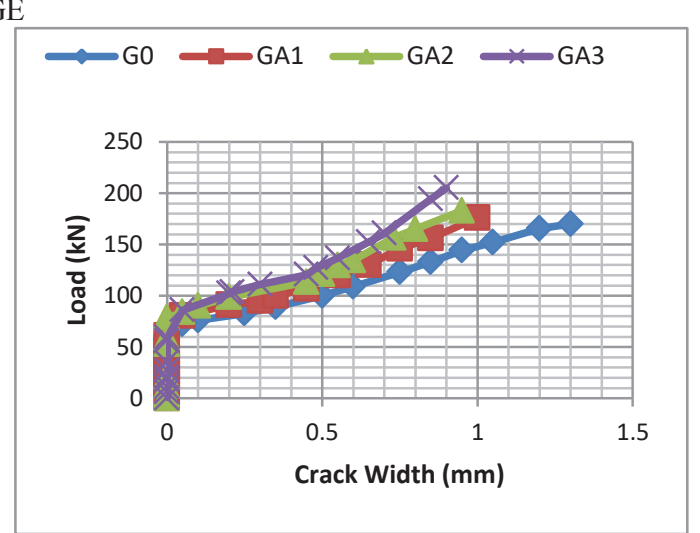

Fig. 8. Load - crack width curve for specimens of group GA

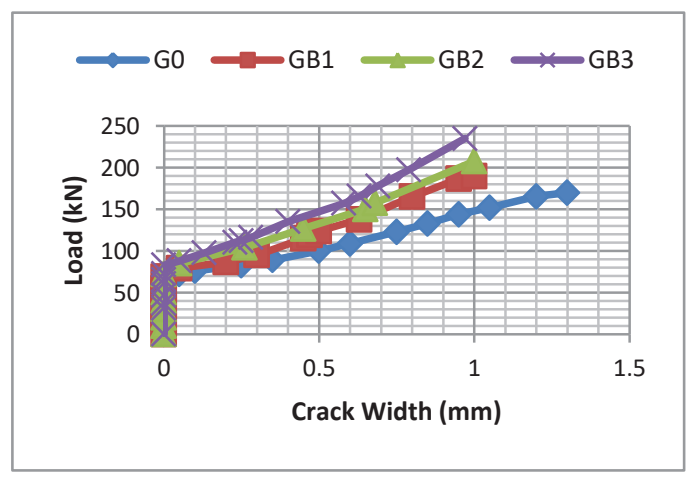

Fig. 9. Load - crack width curves for specimens of group GB

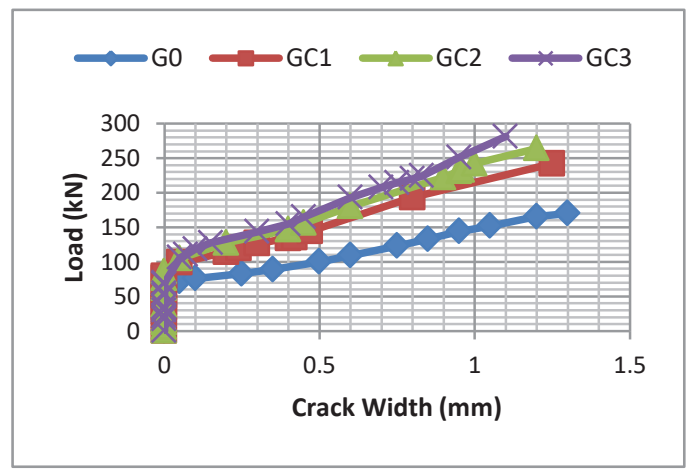

Fig. 10. Load - crack width curve for specimens of group GC 


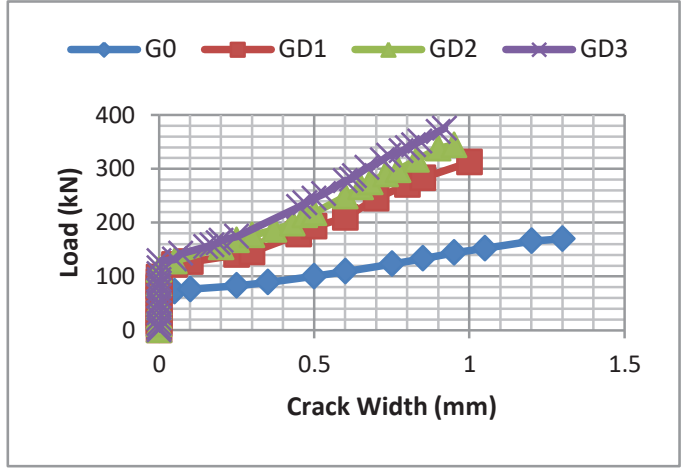

Fig. 11. Load - crack width curves for specimens of group GD

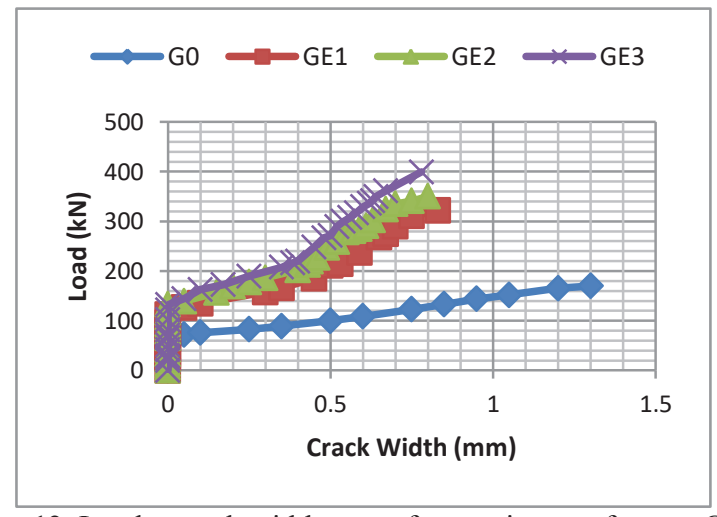

Fig. 12. Load - crack width curve for specimens of group GE

\section{Serviceability requirements}

\subsection{Deflection}

The ACI code kindly recheck table to calculate the maximum permissible deflections $318-\mathrm{M}-14$ for slabs [2]. The deflection limitation obtained from the ACI code for two way reinforced concrete slab is selected to correspond to $\mathrm{L} / 360$, where $\mathrm{L}$ is the span length. For the slab specimens of $600 \mathrm{~mm}$ span length, this limit will give a service deflection of $1.67 \mathrm{~mm}$. By applying this value of deflection on the load-deflection curves given in Fig.3 the service loads of all sixteen specimens have been determined. These values of service load were multipled by a factor of 1.6 to get the factored load as recommended by ACI 318M-14 code [2]. These factored loads were divided by the corresponding experimental ultimate load to get the percentages. Fig. 13 clarifies the experimental ultimate nominal load (Pn) and the calculated factored load $(\mathrm{Pu})$.

While the B.S8110:part 2:1985 standarad[3] applies a limit to calculate the deflection due to vertical load for structural members that are visible, the sag in a member will usually become noticeable if the deflection exceed L 1250, where L is the span length which was $600 \mathrm{~mm}$. So the service deflection is $2.4 \mathrm{~mm}$, then this value has been applied to the load-deflection curves that are shown in Figs. 3 to 7 to extract the value of the service load of all sixteen specimens. There after these values of service load were multipled by a factor of 1.6 to get the factored load and the last factored values were divided by the corresponding value of experimental ultimate load to get the percentage. Fig. 14 clarifies the experimental ultimate nominal load (Pn) and the calculated service load $(\mathrm{Pu})$.

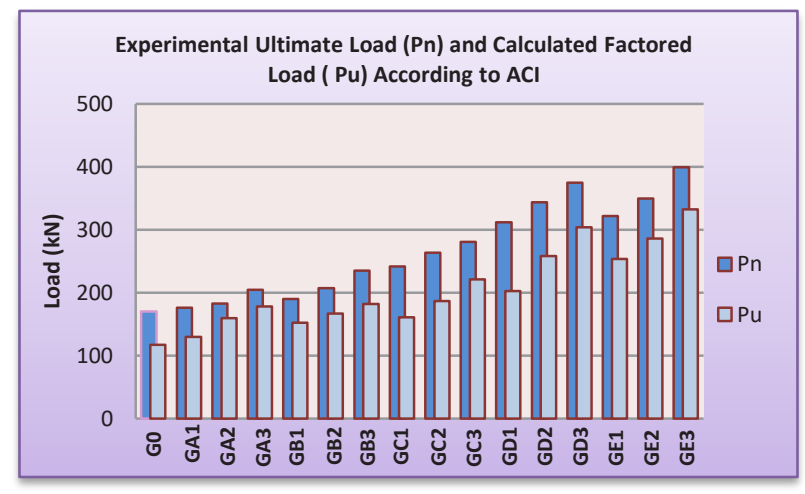

Fig.13. Experimental ultimate load (Pn) and calculated factor

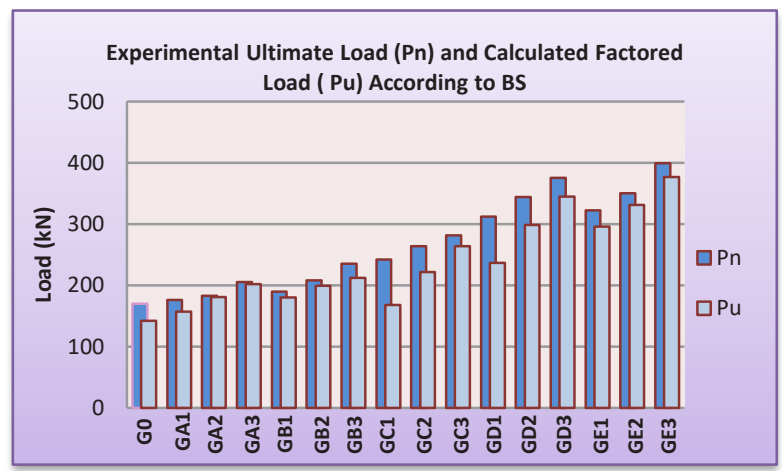

Fig.14. Experimental ultimate load (Pn) and calculated factored load $(\mathrm{Pu})$ based on permissible deflection

\subsection{Crack width}

ACI 318-14 code [2] provisions for allowable crack-width limits in steel-reinforced concrete structures correspond to $0.013 \mathrm{in}$. $(0.3 \mathrm{~mm})$ for exterior exposure and 0.016 in. $(0.4 \mathrm{~mm})$ for interior exposure. Blair and Nawy [4] have provided the following expression, for predicting the maximum crack width:

$$
w=k \beta f_{s} \sqrt{I}
$$

where

$$
I=\frac{d_{b 1} S_{2}}{\rho_{t 1}}=\frac{S_{1} S_{2} d c}{d_{b 1}} \frac{8}{\pi}
$$

$k=$ fracture coefficient with a value $k=2.8 \times 10^{-5}$ for uniformly loaded restrained two-way action square slabs and plates. For concentrated loads or reactions or when the ratio of short to long span is less than 0.75 but larger than 0.5 , a value of $\mathrm{k}=2.1 \times 10^{-5}$ was applicable. For span aspect ratios less than $0.5, \mathrm{k}=1.6$. For simply supported slabs, the value of $\mathrm{k}$ should be multiplied by 1.5 .

$\beta=1.25$ (chosen to simplify calculations, although it varies between 1.20 and 1.35 )

$f_{S}=$ actual average service-load steel (reinforcement) stress level or $40 \%$ of the specified yield strength fy, ksi 
$d_{b 1}=$ diameter of the reinforcement in direction 1 closest to the concrete outer fibers, in.

$\mathrm{S}_{1}=$ the spacing of reinforcement in direction 1, in.

$\mathrm{S}_{2}=$ the spacing of reinforcement in perpendicular Direction 2, in.

$\rho_{t 1}=$ the active steel ratio, that is, the area of steel

$\frac{A_{s}}{\left[12\left(d_{b 1}+2 c_{1}\right)\right]}$

where $\mathbf{A}_{\mathbf{s}}=$ Area of steel per $\mathrm{ft}$

$\mathbf{c}_{1}$ the clear concrete cover measured from the tensile face of the concrete to the nearest edge of the reinforcing bar in direction 1; and,

$\mathbf{w}$ the crack width at face of concrete caused by flexure, in. direction 1 refers to the direction of reinforcement closest to the outer concrete fibers; this is the direction for which crack-control check should be made. Subscripts 1 and 2 pertain to the directions of reinforcement .

The value extracted from the equation above was 0.6 $\mathrm{mm}$ and the code mentions a maximum allowable value equal to $0.4 \mathrm{~mm}$ which should not exceed. So By dropping this crack value $0.4 \mathrm{~mm}$ on the Load-crack width curves that are shown in Figs. 8 to 12, the values of service load of all sixteen specimens has been gained, then these values of service load were multiplied by a factor of 1.6 to get the factored loads and the last values were divided by the corresponding value of experimental ultimate load to get the percentage. Fig. 15 clarifies the experimental ultimate load (Pn) and the calculated factored load $(\mathrm{Pu})$.

While BS 8110-97[5] standarad recommends that the design surface crack width should not exceed a specific appropriate value. Cracking should not lead to spoil appearance. So for members that are visible, the calculated maximum crack width should not exceed 0.3 $\mathrm{mm}$. Also, cracking should not lead to steel corrosion, so for members in aggressive environment the calculated maximum crack width should not lead to a loss of the performance of the structure. BS 8110-97[5] provisions are based on Beeby [6] empirical equations.

Design surface crack width, $W_{d}$

$$
=\frac{3 a_{c r} \varepsilon_{m}}{1+2\left(\frac{a_{c r}-c_{\min }}{h-x}\right)}
$$

where:

$\mathbf{a}_{c r}=$ distance from the point considered to the surface of the nearest longitudinal bar;

$$
\mathbf{a}_{c r}=\sqrt{\left(\frac{S}{2}\right)^{2}+\left(c+\frac{d_{b}}{2}\right)^{2}}-\frac{d_{b}}{2}
$$

$\boldsymbol{\varepsilon}_{\boldsymbol{m}}=$ average strain at the level where the cracking is being considered;

S: reinforcement spacing $(\mathrm{mm})$

$\mathbf{d}_{\mathbf{b}}$ : diameter of reinforcement $(\mathrm{mm})$

$\mathbf{c}_{\min }=$ minimum cover to the tension steel;

$\mathrm{h}=$ overall depth of the member;

$\mathrm{x}=$ depth of neutral axis

For cracked section, the value of $€ m$ is expressed as:

$$
\varepsilon_{m}=\varepsilon_{1}-\frac{\mathbf{b}(\mathbf{h}-\mathbf{x})\left(\mathbf{a}^{\prime}-\mathbf{x}\right)}{3 E s A s(d-x)} \quad \ldots
$$

where: $\varepsilon_{1}=$ strain at the level considered, calculated ignoring the stiffening effect of the concrete in the tension zone,

$$
\varepsilon_{1}=\frac{d-x}{h-x} * \varepsilon_{s}
$$

$\boldsymbol{\varepsilon}_{\mathbf{s}}=\frac{\mathbf{F}_{\mathrm{s}}}{\mathbf{E}_{\mathrm{s}}}$ where $\mathbf{F}_{\mathrm{s}}$ should not exceed $0.8 \mathrm{fy}$, thus, let.

$$
\boldsymbol{\varepsilon}_{\mathrm{s}}=0.8 * \frac{\mathrm{F}_{\mathrm{y}}}{\mathrm{E}_{\mathrm{s}}}
$$

$\mathrm{b}=$ width of the section at the centroid of the tension steel,

$\mathrm{a}^{\prime}=$ distance from the compression face to the point at which the crack width is being calculated $=\mathrm{h}$

The value obtained from the equation above was 0.287 $\mathrm{mm}$ which was consistent with the specified value in the code. Then this value $(0.287 \mathrm{~mm})$ has been used in the load-crack width curves that are shown in Figs. 8 to 12 to extract the value of the service load of all sixteen specimens, after that these values of service load were multiplied by a factor of 1.6 to gain the factored load and the last factored values were divided by the corresponding value of ultimate load to get the percentage. Fig. 16 clarifies the experimental ultimate load $(\mathrm{Pn})$ and the calculated factored load $(\mathrm{Pu})$.

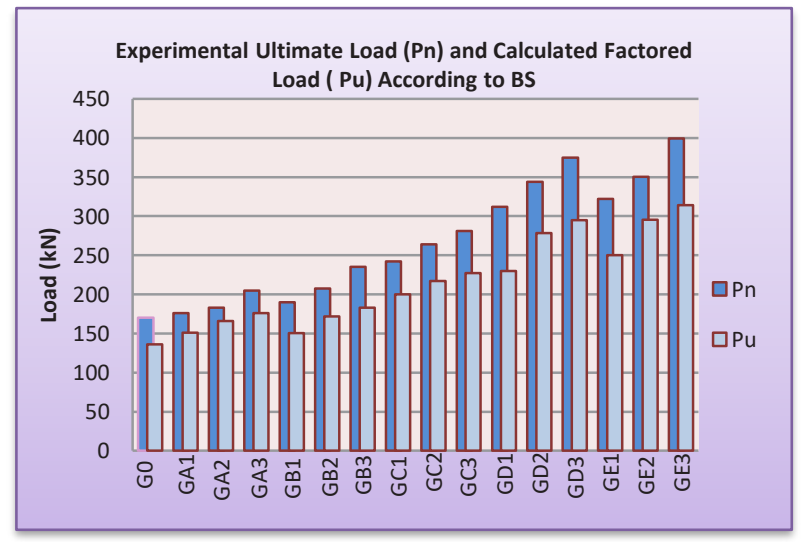

Fig.15. Experimental ultimate load $(\mathrm{Pn})$ and calculated factored load $(\mathrm{Pu})$ based on permisible crack width

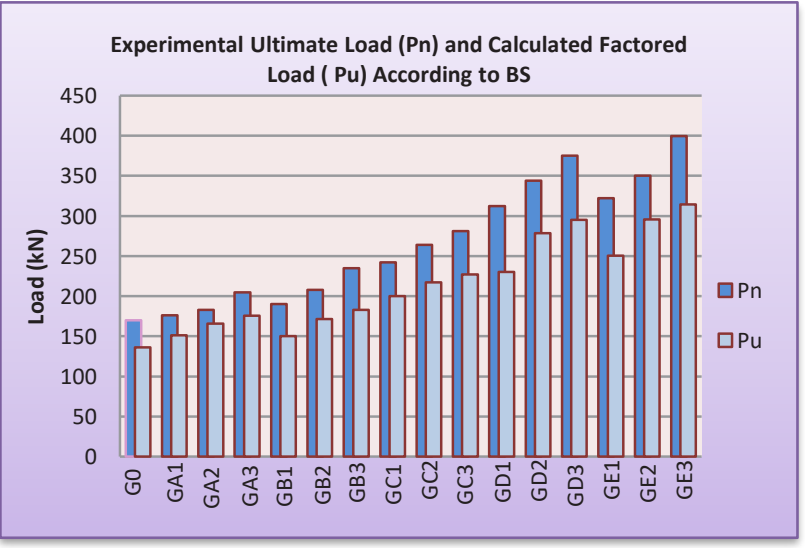

Fig.16. Experimental ultimate load (Pn) and calculated factored load $(\mathrm{Pu})$ based on permissible crack width 
Table 4 shows the ratio of experimental ultimate load $(\mathrm{Pn})$ and calculated factored load $(\mathrm{Pu})$ to the corresponding values of control (unstrengthend) slab specimen. Also, this table shows that the slab with CFRP laminate strengthening GE3 has the greatest gain percentage of $135 \%$ in ultimate load for experimental results. While NRM ferrocement with one layer of steel mesh specimen GA1 gave the lowest gain percentage of $3.5 \%$ in ultimate strength. On the other hand, the ultimate loads that have been calculated based on ACI and BS requirements for both deflections and crack widths revealed similar trend. The highest percentages of gains in strength using ACI code formulae for both deflection and crack widths were $183 \%$ and $138 \%$ while for BS formulae they were $164 \%$ and $131 \%$ respectively. Also, specimen GAl got the lowest percentages in strengths which were $10 \%$ and $12 \%$ based on ACI requirement for both deflection and crack widths, respectively. For BS formulae the percentages were $10 \%$ and $11 \%$, for both deflection and crack widths formulae, respectively.

Table 5 shows the ratios of the calculated factored loads $(\mathrm{Pu})$ based on permissible deflection and crack width to experimental ultimate load (Pn) according to ACI and BS provisions. The average value of this ratio is 0.8 .

\section{Conclusions}

From this experiment, the following conclusions can be drawn:

1. Strengthening ratios within each strengthening technique had a clear effect on the behavior of the strengthened slabs. It was seen that the increase in the ratio of strengthening led to an increase in the ultimate strength in all types of strengthening.

2. The increased in the strengthening ratios of all the five techniques tends to increase the initial cracking and a decrease in the deflection.

3. The calculated results for ultimate loads based on serviceability requirements (deflection and crack width according to both ACI and BS formule) were lower than the experimental results.

4. Generally, the ultimate strength determination using deflection gives more conservative values than that based on crack width.

5. Service load of B.S formula based on permissible deflection gave values higher than ACI formula service load. While for crack width requirements, they gave approximately equal values.

6. NRM ferrocement strengthening technique has the least value of gain in service strength, while the CFRP laminate strengthening gave the highest value.

\section{References}

1. Z.S. Sharhan, Master Thesis, Building and Construction Engineering Department, University of Technology, Baghdad, (2016)

2. ACI 318M-14, 2014. Building Code Requirements for Structural concrete ( ACI 318M-14) and Commentary, USA: American Concrete Institute, (2014)

3. BS 8110: part 2, British Standard use of concrete, code of practice for special circumstances, (1985)

4. E. G. Nawy, K. W. Blair, SP-30, American Concrete Institute, Farmington Hills, Mich., pp. 1-41, (1971)

5. BS 8110-1997. Structural use of concrete, Part 1: Code of practice for design and construction, (1997)

6. A.W. Beeby, SP-20, American Concrete Institute, Detroit, 1971, pp. 55-75 (cited by Makhlouf and Malhas (1996) 
Table 4. Ratio of experimental load (pn) and calculated factored load (pu) of strengthed slabs to control slab

\begin{tabular}{|c|c|c|c|c|c|}
\hline \multirow{6}{*}{$\begin{array}{c}\text { Samples } \\
\text { Name }\end{array}$} & \multirow{6}{*}{$\begin{array}{l}\text { Experimental } \\
\text {. } \\
\frac{\mathbf{P}_{\mathbf{n}}}{\mathbf{P}_{\mathbf{n} \text {.control }}}\end{array}$} & \multicolumn{4}{|c|}{ Calculated } \\
\hline & & \multicolumn{2}{|r|}{ Deflection } & \multicolumn{2}{|c|}{ Crack width } \\
\hline & & \multirow{4}{*}{$\begin{array}{l}\text { ACI code } \\
\qquad \begin{array}{r}P_{u} \\
P\end{array}\end{array}$} & \multirow{3}{*}{$\begin{array}{r}\text { B.S standarad } \\
P_{u} \\
\end{array}$} & \multirow{3}{*}{$\begin{array}{c}\text { ACI code } \\
\qquad P_{u} \\
\end{array}$} & \multirow{3}{*}{$\begin{array}{r}\text { B.S standarad } \\
\boldsymbol{P}_{u} \\
\end{array}$} \\
\hline & & & & & \\
\hline & & & & & \\
\hline & & & $\overline{\boldsymbol{P}_{\text {u,control }}}$ & $\overline{\boldsymbol{P}_{\text {u.control }}}$ & $\bar{P}_{\text {ucontro }}$ \\
\hline G0 & 1 & 1 & 1 & 1 & 1 \\
\hline GA1 & 1.04 & 1.10 & 1.10 & 1.12 & 1.11 \\
\hline GA2 & 1.08 & 1.36 & 1.27 & 1.19 & 1.22 \\
\hline GA3 & 1.21 & 1.52 & 1.42 & 1.27 & 1.29 \\
\hline GB1 & 1.12 & 1.29 & 1.27 & 1.17 & 1.10 \\
\hline GB2 & 1.22 & 1.42 & 1.40 & 1.31 & 1.26 \\
\hline GB3 & 1.38 & 1.55 & 1.49 & 1.39 & 1.35 \\
\hline GC1 & 1.42 & 1.37 & 1.18 & 1.45 & 1.47 \\
\hline GC2 & 1.55 & 1.59 & 1.55 & 1.58 & 1.60 \\
\hline GC3 & 1.65 & 1.88 & 1.85 & 1.67 & 1.67 \\
\hline GD1 & 1.84 & 1.73 & 1.66 & 1.80 & 1.69 \\
\hline GD2 & 2.02 & 2.20 & 2.10 & 2.08 & 2.04 \\
\hline GD3 & 2.21 & 2.59 & 2.42 & 2.32 & 2.17 \\
\hline GE1 & 1.89 & 2.16 & 2.08 & 1.89 & 1.84 \\
\hline GE2 & 2.06 & 2.43 & 2.32 & 2.19 & 2.16 \\
\hline GE3 & 2.35 & 2.83 & 2.64 & 2.38 & 2.31 \\
\hline
\end{tabular}

Table 5. Ratio of experimental load (pn) and calculated factored load (pu)

\begin{tabular}{|c|c|c|c|c|c|c|c|c|c|}
\hline \multirow{4}{*}{ Samples } & \multirow{4}{*}{$\begin{array}{c}\text { Experimental } \\
\\
\text { Ultimate } \\
\text { Load (Pn) } \\
\text { (kN) }\end{array}$} & \multicolumn{8}{|c|}{ Calculated factored load (Pu) } \\
\hline & & \multicolumn{4}{|c|}{ Deflection } & \multicolumn{4}{|c|}{ Crack width } \\
\hline & & \multicolumn{2}{|c|}{ ACI Code } & \multicolumn{2}{|c|}{ B.S standards } & \multicolumn{2}{|c|}{ ACI Code } & \multicolumn{2}{|c|}{ B.S standards } \\
\hline & & $\mathbf{P u}$ & $\begin{array}{c}\mathbf{P u} / \mathbf{P} \\
\mathrm{n}\end{array}$ & $\mathbf{P u}$ & $\begin{array}{l}\mathrm{Pu} / \\
\mathrm{Pn}\end{array}$ & $\mathbf{P u}$ & $\mathbf{P u} / \mathbf{P n}$ & $\mathbf{P u}$ & $\mathbf{u} / \mathbf{P n}$ \\
\hline G0 & 170 & 117.54 & 0.69 & 142.4 & 0.84 & 148.27 & 0.87 & 136.15 & 0.80 \\
\hline GA1 & 176 & 129.76 & 0.74 & 156.8 & 0.89 & 165.6 & 0.94 & 151.17 & 0.86 \\
\hline GA2 & 183 & 159.79 & 0.87 & 181.01 & 0.98 & 176.83 & 0.97 & 166.06 & 0.91 \\
\hline GA3 & 205 & 178.27 & 0.87 & 201.71 & 0.98 & 187.73 & 0.92 & 175.91 & 0.86 \\
\hline GB1 & 190 & 152.16 & 0.8 & 180.44 & 0.94 & 173.6 & 0.91 & 150.41 & 0.79 \\
\hline GB2 & 207.7 & 167.26 & 0.81 & 198.87 & 0.96 & 193.52 & 0.93 & 171.63 & 0.83 \\
\hline GB3 & 235 & 182.02 & 0.78 & 212.25 & 0.90 & 206.13 & 0.88 & 183.13 & 0.78 \\
\hline GC1 & 242.2 & 161.13 & 0.67 & 168 & 0.69 & 214.56 & 0.89 & 200.20 & 0.83 \\
\hline GC2 & 264 & 187.11 & 0.71 & 221.34 & 0.84 & 234.24 & 0.89 & 217.25 & 0.82 \\
\hline GC3 & 281.2 & 221.17 & 0.79 & 264 & 0.94 & 247.36 & 0.88 & 227.24 & 0.81 \\
\hline GD1 & 312 & 203.04 & 0.65 & 236.57 & 0.76 & 267.46 & 0.86 & 230.08 & 0.74 \\
\hline GD2 & 344.1 & 258.5 & 0.75 & 298.56 & 0.87 & 307.68 & 0.89 & 278.29 & 0.81 \\
\hline GD3 & 375.1 & 304 & 0.81 & 344.41 & 0.92 & 344.6 & 0.92 & 294.97 & 0.79 \\
\hline GE1 & 322 & 253.74 & 0.79 & 296 & 0.92 & 280.96 & 0.87 & 250.41 & 0.78 \\
\hline GE2 & 350.2 & 286.16 & 0.82 & 330.97 & 0.95 & 324 & 0.93 & 295.50 & 0.84 \\
\hline GE3 & 399.4 & 332.64 & 0.83 & 376.39 & 0.94 & 352.16 & 0.88 & 314.19 & 0.79 \\
\hline
\end{tabular}

